\title{
The Branching and Branch Shedding of Bothrodendron.
}

\author{
BY \\ MARJORIE LINDSEY. \\ With Plate XI and three Figures in the Text.
}

INTRODUCTION.

THE object of this paper is to bring forward some new evidence with 1 regard to the ulodendroid scars of Bothrodendron, and to discuss the ulodendroid condition both in this genus and in Lepidodendron.

From very early in the history of Palaeobotany these two genera have been known to bear, in certain cases, two opposite rows of depressed circular scars on their main stems.

Such stems were said to be in the ulodendroid condition, and practically every possible type of appendicular organ has, at one time or another, been suggested as the cause of the scars.

The various theories regarding the ulodendroid scars may therefore be grouped under five heads, representing the five possible types of appendicular organ.

We have then :-

I. The floral theory, put forward by Rhode, and agreed to by Allan (1), who compared the plant with a cactus.

2. The root theory, first suggested by Brongniart and more fully discussed by Carruthers (3). This was refuted by Williamson (14) and Thompson (11).

3. The bulbil theory of Stur (10), which was in its turn refuted by Schimper (8).

4. The cone theory due in the first place to Lindley and Hutton (5), but confirmed by many others, notably Thompson (11). For long this was the accepted theory, but it has recently been shown to be improbable by Watson (12) and Renier (7), who prefer

5. The branch theory, originally due to Sternberg.

[Annals of Botany, Vol. XXIX. No. CXIV. A pril, 1915.] 


\section{The Branch Theories of the Origin OF the SCAR.}

In 1907 D. M. S. Watson (12) described a specimen of Bothrodendron in the Manchester Museum, and explained that it showed the ulodendroid scar to be left by a dehiscent branch, the base of which occupied the whole area of the scar.

The surface of the scar showed leaf-traces running out to the branch.

M. Renier (7) in his monograph described a specimen in which a branch of Bothrodendron was seen on one side ' of a very thin plate of shale', while

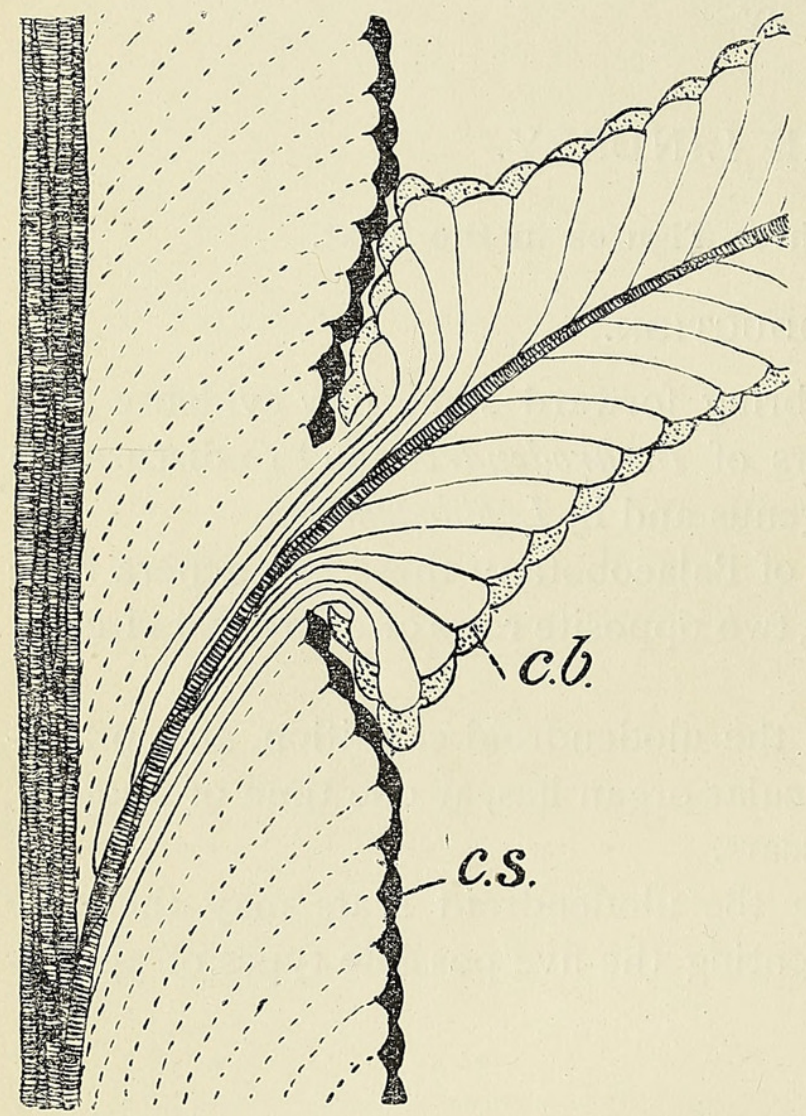

TeXt-FIG. I. Illustrates the umbilical attachment theory. c.b., cortex of branch; c.s., cortex of stem; leaf-traces of stem are represented by dotted lines, leaf-traces of branch by continuous lines; the principal vascular axes are shaded. in the same position, on the other side, was a ulodendroid scar with an eccentric umbilicus. He describes this as indisputable evidence in favour of the branch theory. But, arguing from specimens of Lepidodendron, his conclusions as to the way in which the branch was joined to the stem show that his conception of a branch theory differs fundamentally from Watson's. The one (Watson's) supposes the branch to have been attached to the whole area of the scar, and to have been provided with some branchshedding mechanism such as a layer of cork, and may therefore be described as the Abscission Layer Theory.

The other (Renier's) supposes the branch to have been attached to the stem by the umbilicus alone, that the branch 'had a conical base like the branch of a calamite', and that the rest of the scar was formed by pressure as the branch and trunk grew in size simultaneously. This may therefore be known as the Umbilical Attachment Theory.

Text-figs. I and 2 show the essential differences between these two theories; in the case of the umbilical attachment theory the cortex of the branch was supposed to adhere to that of the stem over the area of the scar. Therefore the markings on the scar represent the markings on the inner side of the outer cortex of the branch, and bear no relationship with the leaf-traces of the stem. 
In a more recent paper in the Annals of Botany, July, I9I4, Mr. Watson (13) has discussed these two theories, objecting to the umbilical attachment theory on the following grounds :

I. The relative insignificance of the secondary thickening in any lepidodendroid plant as compared with that which would be required by M. Renier's theory.

2. No ulodendroid scars are known in which the diameter of the umbilicus is more than a quarter of the diameter of the scar; that is, the first stages as required by the umbilical attachment theory are unknown.

3. The weakness of the calamite branch analogy.

4. The evidence of structure material shows no contraction at the base.

5. In the two new sections described by Mr. Watson the whole base of branch is cut off by a thick layer of secondary tissue ; that is, there is a definite abscission layer.

There are only two additional arguments which I should like to bring forward. For the sake of argument, Mr. Watson admits M. Renier's contention that the leaf-trace markings on both halves of his specimen do not correspond in position. But if the figure of

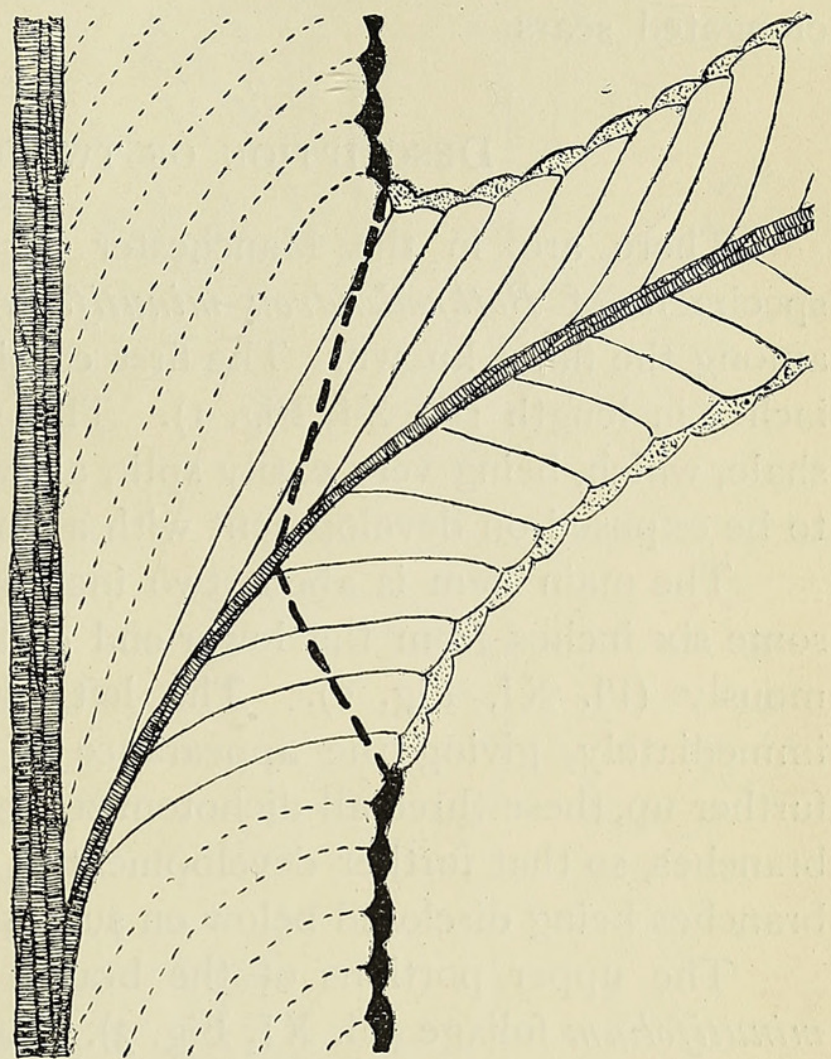

TeXT-Fig. 2. Illustrates the abscission layer theory. The heavy broken line marks position of abscission layer; otherwise as in Text-fig. I. one half of the specimen is traced and the tracing reversed on to the figure of the other half, it will be seen that the leaf-trace markings agree very closely in position and are equal in number.

The second point concerns the arrangement of the leaf-trace markings on the scar. In the specimens figured by M. Renier and in many other well-known figures such as those of Stur, the quincuncial arrangement of the leaf-traces on the trunk is continued on the lower part of the scar, and this was used as an argument that the scar, except the umbilicus, was of the same nature as the trunk-that it was, in fact, merely a flattened portion thereof. But this does not take into consideration the fact that on the upper part of the scar the leaf-traces are very differently arranged. On the abscission layer theory the whole area of the scar simply represents 
the plane of separation of a fallen branch, and the leaf-traces passing out to the branch would of necessity cut this plane of separation and leave their impressions thereon. The leaf-trace markings on the lower part of the scar would be more or less in continuity with those on the stem below, because the leaf-traces belong to the same phyllotactic series in both and cut the abscission layer and the stem at approximately the same angle in both. On the upper part of the scar, however, it will be seen from Text-fig. 2 that the leaf-traces run almost parallel to the plane of the scar, and so they would appear not as small punctations or dots, but as an irregular series of elongated scars.

\section{Description of tWo NeW Specimens.}

There are in the Manchester Museum two hitherto undescribed specimens of Bothrodendron minutifolium; these two new specimens are among the finest known. The first consists of a large branch some fifteen inches in length (Pl. XI, Fig. I). This was partly exposed in a matrix of shale, which, being very easily split, allowed further portions of the branch to be exposed on development with a small chisel.

The main stem is about two inches in diameter, and at a distance of some six inches from the lower end of the specimen it branches dichotomously (Pl. XI, Fig. 2). The left branch dichotomizes again almost immediately, giving the appearance of three equal branches. Slightly further up, these three all dichotomize freely, forming a bushy mass of small branches, so that further development in this region merely leads to further branches being disclosed below on successive layers of shale.

The upper portions of the branch show the typical Bothrodendron minutifolium foliage (Pl. XI, Fig. 3). Lower down, this foliage has fallen off, leaving the spirally arranged oval scars plainly visible. These scars have the three punctations representing the vascular bundle and the parichnos, and above each is seen the impression of the ligular pit.

They are separated from each other by about half an inch, and the area between is marked by transverse furrows. As was mentioned by Zeiller (15), when more highly magnified the ridges between the furrows are seen to be covered by a number of raised circular structures, with a depression in the centre of each. It is not quite clear what these represent, but they are possibly in the nature of stomata.

But it is the base of the specimen which renders it so valuable (Pl. XI, Fig. 2). The base of the stem on development was found gradually to broaden out into a trumpet-shaped body, and then to end quite suddenly and cleanly in a convex edge, which corresponds in size with the diameter of an ordinary ulodendroid scar. This convex edge was not due to accident in fossilization, but was really the true ending of the branch. The rest of 
the preservation is so excellent that had the branch been any longer or in any way different in form, it would most certainly have shown the fact quite clearly.

The other specimen (P1. XI, Fig. 4) is of rather a different nature: it consists of what appears to be the termination of a main trunk, which gives off branches in two opposite and alternate rows-an entirely new form of branching for a Bothrodendron.

The various surface features, such as leaf scars, are nearly as well preserved as in the first specimen. The main axis is about fourteen inches in length and is an inch in diameter in its widest part. There are five branches well shown, and these each have a broadened trumpet-shaped base. Some are seen to dichotomize at a short distance from the main stem. (See Text-fig. 3.) Others show clear evidence of the spreading, bushy mass of small branches which characterized the other specimen. This is well shown in the lowest branch exposed. Here we have a branch the base of which gradually broadens out until it is about two and a half times the size of the branch itself in diameter. This is exactly the relation in size of the branch to its base in the first specimen, and at a similar distance in both the branches dichotomize and spread out. In both, also, further branches below are exposed on excavation, and in both the foliage is retained

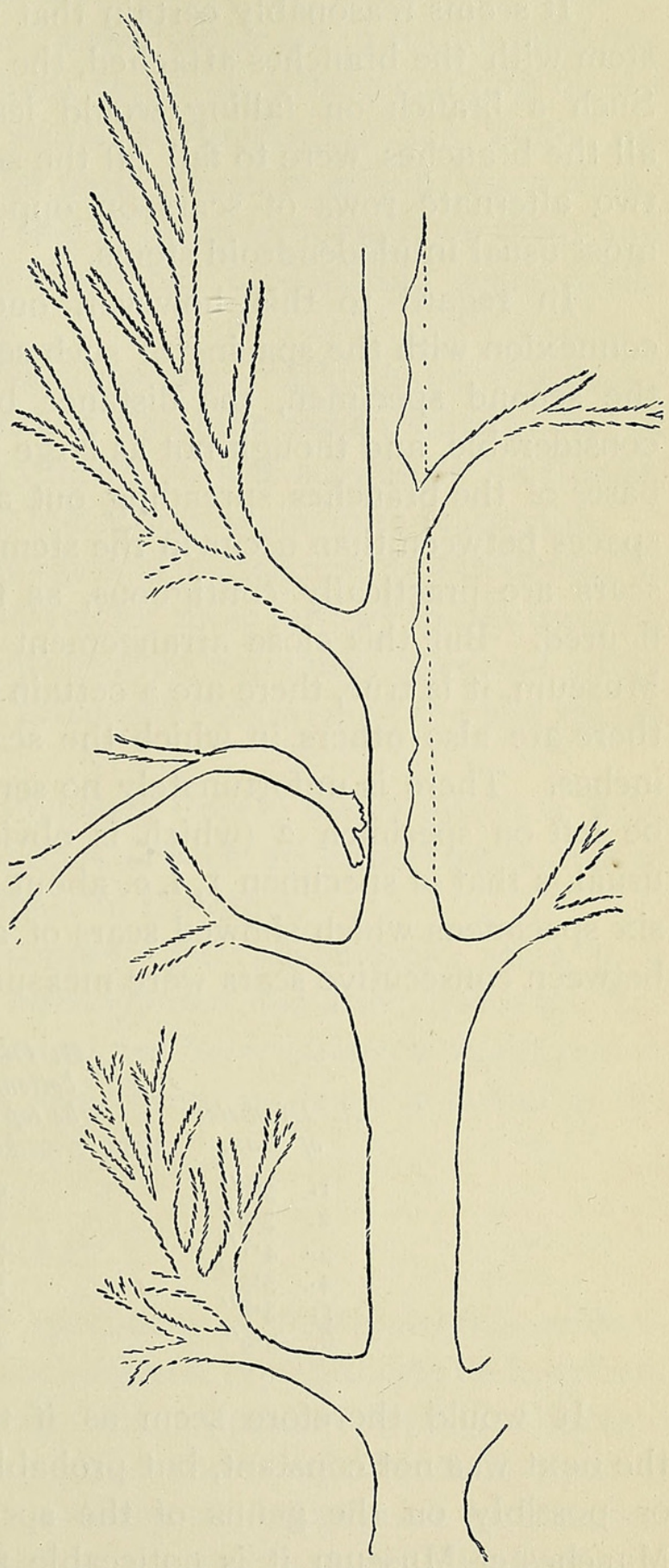

TEXT-FIG. 3. Bothrodendron minutifolium. $\frac{1}{3}$ nat. size.

on the upper portion, while lower down it has fallen away, leaving typical leaf scars.

A very important point to notice in connexion with this specimen is the fact that the cortex of the branch is continuous with that of the main 
stem. From this it seems clear that the branch was attached to the stem in a quite normal way, and not in the manner in which M. Renier supposes, for in the latter case there would be a distinct ring where the cortex of the stem joined that of the branch.

It seems reasonably certain that while the second specimen is a main stem with the branches attached, the first is a branch which has fallen off. Such a branch on falling would leave a ulodendroid scar. Supposing all the branches were to fall off the second specimen you would then have two alternate rows of scars on opposite sides of a main axis just as is most usual in ulodendroid stems.

In regard to this, however, one question crops up, and that is in connexion with the spacing of such scars. Should the branches fall from the second specimen, the distance between consecutive scars would be considerable, and though not as large as appears at first sight owing to the bases of the branches spreading out as they do, still it would leave larger spaces between than occur in the stems figured by M. Renier. In these the scars are practically contiguous, as they are in a good many specimens figured. But this close arrangement is not universal. In the Manchester Museum, it is true, there are a certain number of examples of this type, but there are also others in which the scars have a separation of eight or nine inches. There is unfortunately no series of scars of the size such as would be left on specimen 2 (which is obviously far from full-grown); the most usual is that of specimen I, i. e. about $3 \frac{3}{4}$ inches in diameter. Taking, then, six specimens which showed scars of approximately this size, the distances between consecutive scars were measured with the following results:

$\begin{array}{ccr} & \begin{array}{c}\text { B. Distance from } \\ \text { bottom of scar to } \\ \text { the top of the scar }\end{array} & \text { C. Index } \\ \text { A. Diameter } & \text { below. } & A \\ \text { of Scar. } & 9 \cdot 5^{\prime \prime} & 0 \cdot 30 \\ \text { I. } 3 \cdot 8^{\prime \prime} & 8 \cdot \mathbf{I}^{\prime \prime} & 0 \cdot 33 \\ 2.3 \cdot 6^{\prime \prime} & 7 \cdot 0^{\prime \prime} & 0 \cdot 58 \\ 3.4 \cdot \mathbf{I}^{\prime \prime} & 5 \cdot 4^{\prime \prime} & 0 \cdot 66 \\ 4.3 \cdot 5^{\prime \prime} & 2 \cdot 9^{\prime \prime} & \mathrm{I} \cdot 3 \mathrm{I} \\ 5.3 \cdot 8^{\prime \prime} & 2 \cdot 3^{\prime \prime} & \mathrm{I} \cdot 69\end{array}$

It would therefore seem as if the distance between one scar and the next was not constant, but probably depended on conditions of growth, or possibly on the genus of the specimen, for in the specimens in the Manchester Museum it is noticeable that the scars on Bothrodendron are, on the whole, further apart than those of Ulodendron proper, and it has already been pointed out that the specimens figured by Renier are Lepidodendron, whereas the two new specimens are Bothrodendron. There are not, however, enough specimens of Ulodendron majus (i. e. the lepidodendroid form) from which to state this as a definite assertion, but it does seem quite reasonable. 


\section{RELATION OF BOTHRODENDRON PUNCTATUM TO BOTHRODENDRON}

\section{MINUTIFOLIUM.}

In the paper by Renier (7) mentioned before, he states that Bothrodendron punctatum and Bothrodendron minutifolium are in reality only one species-in fact, that he has found both types of surface-marking on the same specimen. In both, the leaf scars are practically the same, the difference between them being $(a)$ the bark (which in minutifolium shows transverse furrows, while punctatum is said to be longitudinally marked), and (b) the fact that Bothrodendron punctatum has ulodendroid scars, while Bothrodendron mimutifolium has none.

Decidedly B. minutifolium shows transverse markings on the bark; but whether the markings in $B$. punctatum are of the same nature or due to a splitting of the bark consequent on growth, as was suggested by Renier, I am unable to say from observations, but it does seem quite reasonable.

As to the other point, $(b)$, in many cases of ulodendroid Bothrodendrons the surface is not sufficiently well preserved for these furrows to be observed, and so it may be that many large stems bearing scars may have had either one kind of marking or the other, the presence of scars being the sole reason for their being called punctatum.

In any case the two species are obviously closely allied, and it is quite probable that what happens in one species in such an important matter as branch-shedding will have its counterpart in the other.

Therefore if Bothrodendron punctatum had ulodendroid scars it is at least probable that Bothrodendron minutifolium had also; hence the fact that the two new specimens here described are Bothrodendron minutifolium need be no serious argument against their being evidence in favour of the abscission layer theory of the ulodendroid scar.

\section{SUMMARY.}

In the foregoing paper two new specimens of Bothrodendron minutifolium are described---one showing branching of a type hitherto undescribed. It consists of the end of a main axis with opposite rows of alternate branches with trumpet-shaped bases. The cortex of the main stem is continuous with that of the branches, showing the branches to be attached in quite a normal way. These branches themselves show the ordinary bushy, spreading mass of small branches usual in known Bothrodendrons.

It is equally clear that the other specimen is a similar though larger branch which has fallen away -its clean-cut, trumpet-shaped ending suggesting that it has broken away along a definite abscission layer.

Though previously described Bothrodendrons in the ulodendroid condition have been attributed to Bothrodendron punctatum, the fact that 
these new specimens are Bothrodendron minutifolium is not an insurmountable difficulty, since these two species, if not identical, are at any rate very closely allied, and it is therefore quite probable that both had the same method of shedding.

Finally, I wish to express my thanks to Dr. Hickling for his assistance in the preparation of this paper, and also for the photographs with which it is illustrated.

Geological Department,

The University, Manchester.

\section{LITERATURE.}

1. Allan ('23): Trans. Roy. Soc., Edinburgh, vol. ix.

2. Buckland ('36): Geology and Mineralogy.

3. Carruthers ('70): On the Nature of the Stems of Ulodendron, Bothrodendron, and Megaphyton. Monthly Microscopical Journal, vol. iii, p. I 44.

4. Kidston ('85): Relationship of Ulodendron to Lepidodendron, Bothrodendron, and Rhytido. dendron. Annals and Mag. Nat. Hist., vol. xvi, pp. I23-39, \&c.

5. Lindley and HutTon ('33): Fossil Flora.

6. Lomax and Weiss ('05): Lepidodendron selaginoides. Mem. Proc. Manchester Lit. and Phil. Soc., vol. xlix, no. I 7 .

7. Renier ('10): L'origine raméole des cicatrices ulodendroïdes. Annales Soc. géol. de Belgique.

8. Schimper ('80): In Zittel, Handbuch d. Palaeont., Part II.

9. Seward ('10): Fossil Botany, vol. ii.

10. Stur ('75) : Die Culm-Flora. Abhandl. d. k.-k. geol. Reichsanst., Bd. viii, I875.

11. Thompson, D'Arcy ('80): Notes on Ulodendron and Halonia. Trans. Edinburgh Geol. Soc., vol. iii, p. 34I.

12. Watson ('07): On the Ulodendroid Scar. Mem. Proc. Manchester Lit. and Phil. Soc., vol. lii, Part I.

13. ('14): On the Structure and Origin of the Ulodendroid Scar. Annals of Botany, vol. xxviii.

14. Williamson ('72) : Organization of Fossil Plants from the Coal Measures. Phil. Trans. Roy. Soc., vol. clxii.

15. Zeiller ('86): Flore fossile de Valenciennes. Texte, pp. 479-93, Plates LXXIII-LXXVI.

\section{DESCRIPTION OF PLATE XI.}

Illustrating Miss Marjorie Lindsey's paper on the Branching and Branch Shedding of Bothrodendron.

Fig. I. First specimen of Bothrodendron mimutifolium, showing the bushy nature of the branch.

Fig. 2. The base of the first specimen, showing the dichotomy and the trumpet-shaped ending.

Fig. 3. Part of the surface of Bothrodendi on minutifolium, showing leaf cushions with vascular scars and the ligular pit, and also the furrows in between the scars.

Fig. 4. The second specimen of Bothrodendron minutifolium, showing the main axis with alternate branches on each side, each branch of a spreading, bushy nature and with a trumpetshaped base. 
1.
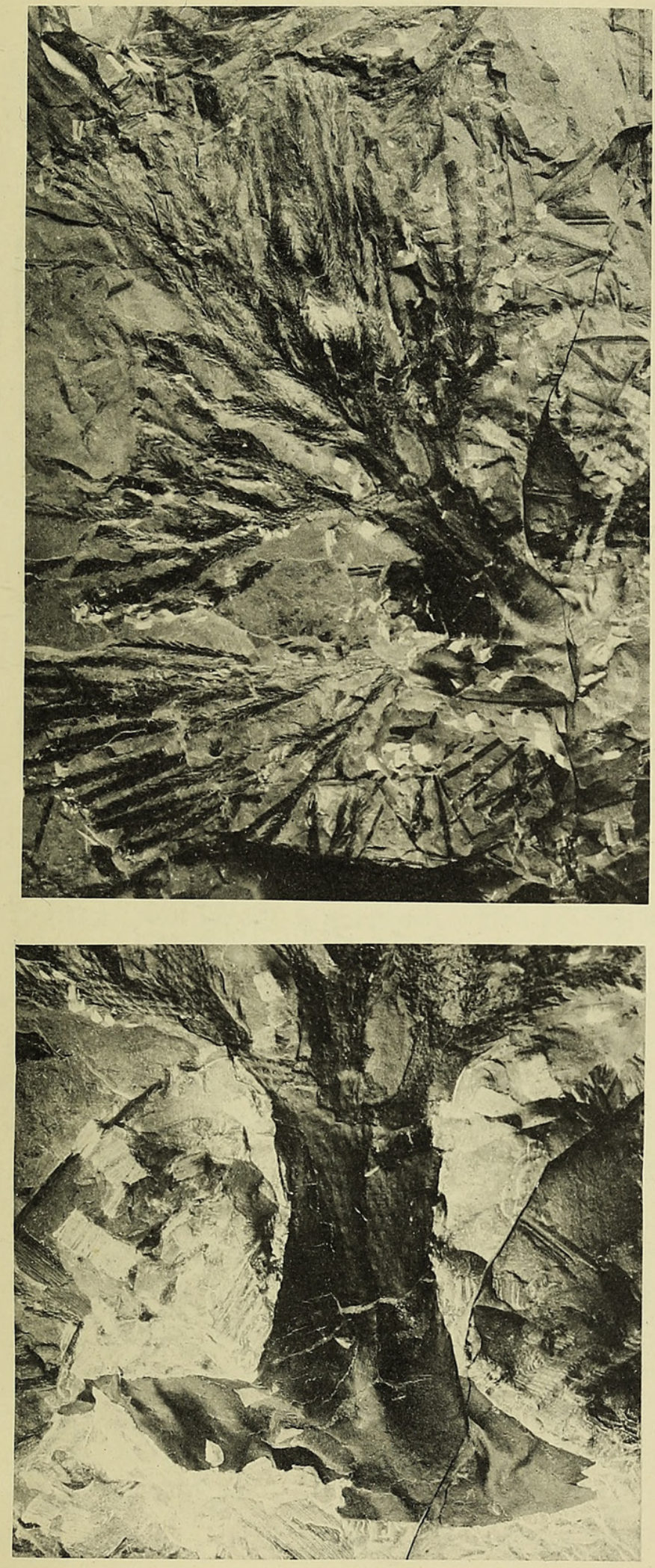

2.
3.
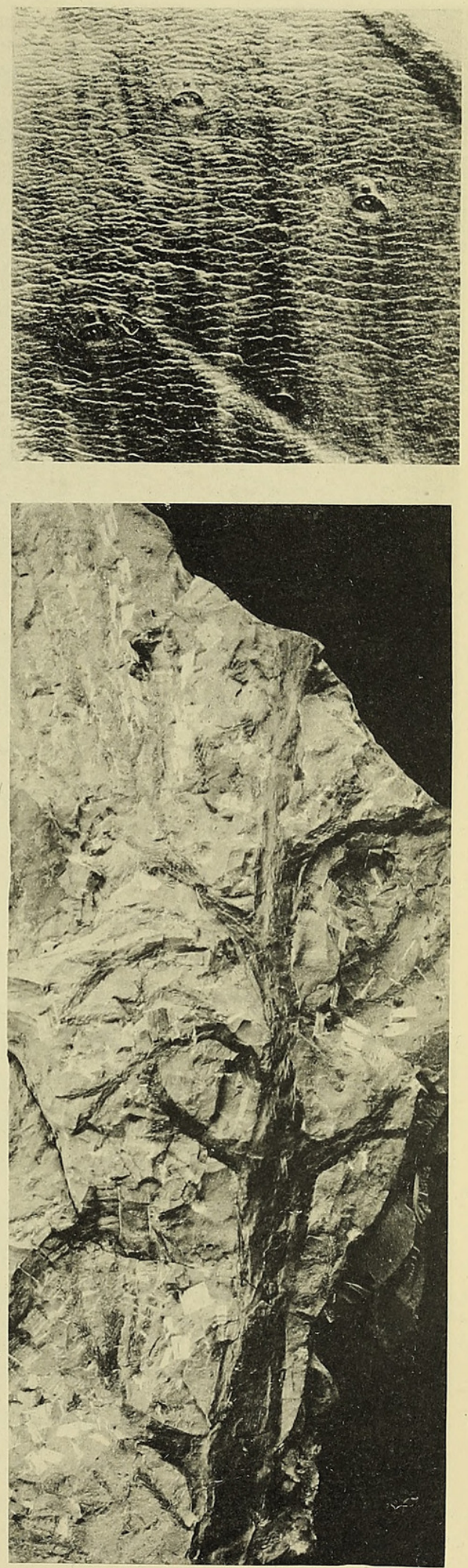

4.

Huth coll.

LINDSEY-BOTHRODENDRON. 


\section{$2 \mathrm{BHL}$ Biodiversity Heritage Library}

Lindsey, Marjorie. 1915. "The branching and branch shedding of Bothrodendron." Annals of botany 29, 223-230. https://doi.org/10.1093/oxfordjournals.aob.a089542.

View This Item Online: https://www.biodiversitylibrary.org/item/243629

DOI: https://doi.org/10.1093/oxfordjournals.aob.a089542

Permalink: https://www.biodiversitylibrary.org/partpdf/320059

\section{Holding Institution}

Smithsonian Libraries

\section{Sponsored by}

Biodiversity Heritage Library

\section{Copyright \& Reuse}

Copyright Status: Not in copyright. The BHL knows of no copyright restrictions on this item.

This document was created from content at the Biodiversity Heritage Library, the world's largest open access digital library for biodiversity literature and archives. Visit BHL at https://www.biodiversitylibrary.org. 